\title{
Relationship Between Organizational Citizenship Behavior and Employee Performance on Hospitality Industry in Surabaya Indonesia
}

\author{
Thomas S. Kaihatu ${ }^{1}$, Michael Adiwijaya ${ }^{2}$, Endo W. Kartika ${ }^{3}$, and Agustinus Nugroho ${ }^{4}$ \\ ${ }^{1,4}$ University of Ciputra, ${ }^{2,3}$ Petra Christian University
}

\begin{abstract}
Employees are one of the important company assets to achieve company vision and mission especially in service industries. Human resource management plays crucial roles in improving employee productivity. Some human resources challenges are low productivity level, employee ignorance, low teamwork, workmates conflict, and many mores. The need for optimal employee working performances is become the main concern for every company since it will influence the company overall performances. The purpose of this research is to investigate the relationship between organizational citizenship behavior and employee performances as well as the measurement for those variables. Total 49 respondents who have been working at four and five hotel in Surabaya, Indonesia. Partial least square is used to analyze the data. The findings showed that organizational citizenship behavior influenced employee performances. Working accuracy is the strongest dimension that supported employee performance variable, meanwhile obedience is the strongest dimension that supported organizational citizenship behavior.
\end{abstract}

Keywords: Organizational Citizenship, Hospitality, Surabaya Indonesia

\section{Introduction}

Nowadays the globalization and free market era demands corporate continuous improvement in purpose to create corporate competitive advantage. Status quo company will be suffered from intense competition [1]. Employees are one of the important company assets to achieve company vision and mission especially in service industries [2]. Human resource management plays crucial roles in improving employees productivity. Some human resources challenges are low productivity level, employee ignorance, low teamwork, workmates conflict, and many mores [3].

The need for optimal employee working performances is become the main concern for every company since it will influence the company overall performances [4]. Employee characteristics or behavior that shows the high level of productivity voluntarily without management supervision is known as organizational citizenship behavior [5]. Moreover, the increasing of organizational citizenship behavior will increase employee performances [6]. The purpose of this research is to investigate the relationship between organizational citizenship behavior and employee performances as well as the measurement for those variables.

\section{Litterature Review}

According to [7] explained that organizational citizenship behavior is the behavior that exceeding formal job description within an organization. Dimension of organizational citizenship behavior based on [8] as follow: firstly is the obedience which refers to the employee respect toward organization regulations and policies; secondly is the loyalty which referes to the employee loyalty to give contribution toward organization development; thirdly is participation which refers to the employee responsibility to get involved in the overall organization operation; fourthly is the morality which refers to the employee norms and customs which are derived from local culture. Meanwhile performance is the result of ability multiply with the efforts and supports; if one of the components is missing then the performances will decrease. Individual ability is influenced by motive, incentives, and working plan as well as the organization support which covers appropriate human resource training. 


\section{Research Conceptual Model}

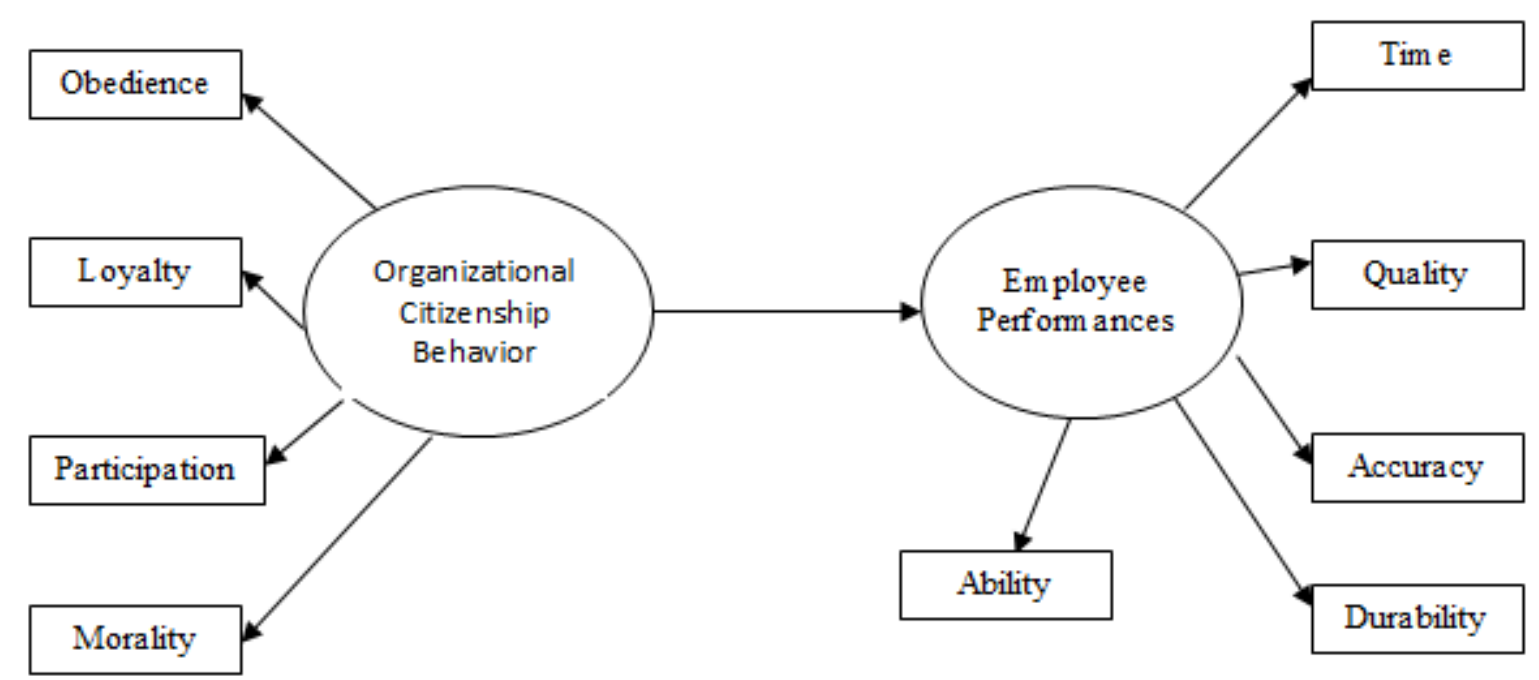

Fig. 1. Proposed Research Model

Organizational citizenship behavior comprises obedience, loyalty, participation, and morality creates favorable working condition within organization environment and as the consequences this condition will lead to the formation of better working productivity level. The obedience of employee towards organization regulations and policies will facilitate them to work based on management direction to achieve organization goals. Next, the increasing of employee participation in managerial decision making will enrich the decision and will create positive working performance for example the working durability and quality [9]. Employee loyalty refers to the emotional bond of employee towards his/her organization. Loyalty measurement can be used to predict employee behavior for instance the turnover level, on time attendance, etc [10]. Therefore the higher employee organizational citizenship behavior will affecting the higher of employee performances.

H1: Organizational citizenship behavior influences employee performances.

\section{Research Methodology}

Population for this research is the employee who has been working at four and five star hotel in Surabaya, Indonesia. Total 49 respondents who are on the middle and top management level are collected for this survey through non probability sampling and purposive sampling technique type. There are two main research variables; the independent research variable is Organizational Citizenship Behavior $\left(\mathrm{X}_{1}\right)$ which is measured by four dimension; they are obedience, loyalty, participation, and morality. The indicators to measure obedience dimension; they are on time working attendance, obedience on regulations, keep clean working environment, and completing working deadline. Next the indictors to measure loyalty dimension; they are working overtime, collecting new information, keeping internal working secret, working responsibility, and reporting unethical working behavior. Moreover, participation dimension comprises some indicators; they are providing innovative input, providing honest opinion, listening other opinion, solving working problem, and joining working training. Finally morality dimension covers risk taking, hard working, and sense of belonging.

Moreover the dependent research variables is Employee Performances $\left(\mathrm{Y}_{1}\right)$ which is measured by five dimension; they are working time, working quality, working accuracy, working durability, and working ability. The indicators for working time; they are working time on regular task and on incidental task. Next for working quality indicators, they are working warranty and reliable working procedures. Working accuracy dimension is measured via several indicators; they are accurate working result, rigorous working result, and working knowledge. While the indicators for working durability are working attitude, working stamina, and working voluntary. Finally, working ability is measured through teamwork (personal and division), support each other, 
and cross work. All indicators were rated through five point Likert scale. Meanwhile partial least square is used to analyze research data.

\section{Findings and Conclusion}

Validity and reliability test are conducted and the result showed that the indicators are greater than 0.5 which mean the indicators are valid. In addition the internal model reliability is good $(>0.07)$ which means the model is reliable.

TABLE 1. Decriptive of OCB

\begin{tabular}{|l|c|c|}
\hline Item & Mean & Std Dev \\
\hline Obedience & 4.18 & 0.499 \\
\hline Loyalty & 3.98 & 0.523 \\
\hline Participation & 3.86 & 0.610 \\
\hline Morality & 4.14 & 0.583 \\
\hline OCB & 4.03 & 0.496 \\
\hline
\end{tabular}

Based on table 1; it can be concluded that the employee, who have been working at four and five star hotel in Surabaya, had high organizational citizenship behavior (4.03). This high mean score is also distributed evenly on four dimension of OCB.

TABLE 2. Decriptive of Performance

\begin{tabular}{|l|c|c|}
\hline Item & Mean & Std Dev \\
\hline Working time & 3.54 & 0.736 \\
\hline Working quality & 3.85 & 0.592 \\
\hline Working accuracy & 3.85 & 0.610 \\
\hline Working durability & 3.61 & 0.583 \\
\hline Working ability & 3.88 & 0.507 \\
\hline Performances & 3.80 & 0.467 \\
\hline
\end{tabular}

Based on table 2; it can be concluded that the employee, who have been working at four and five star hotel in Surabaya, had relatively high performance (3.80). This high mean score is also distributed evenly on three dimension of performances; they are working quality, working accuracy, and working ability. Meanwhile the other two dimensions (working time and working durability) are considered on the average

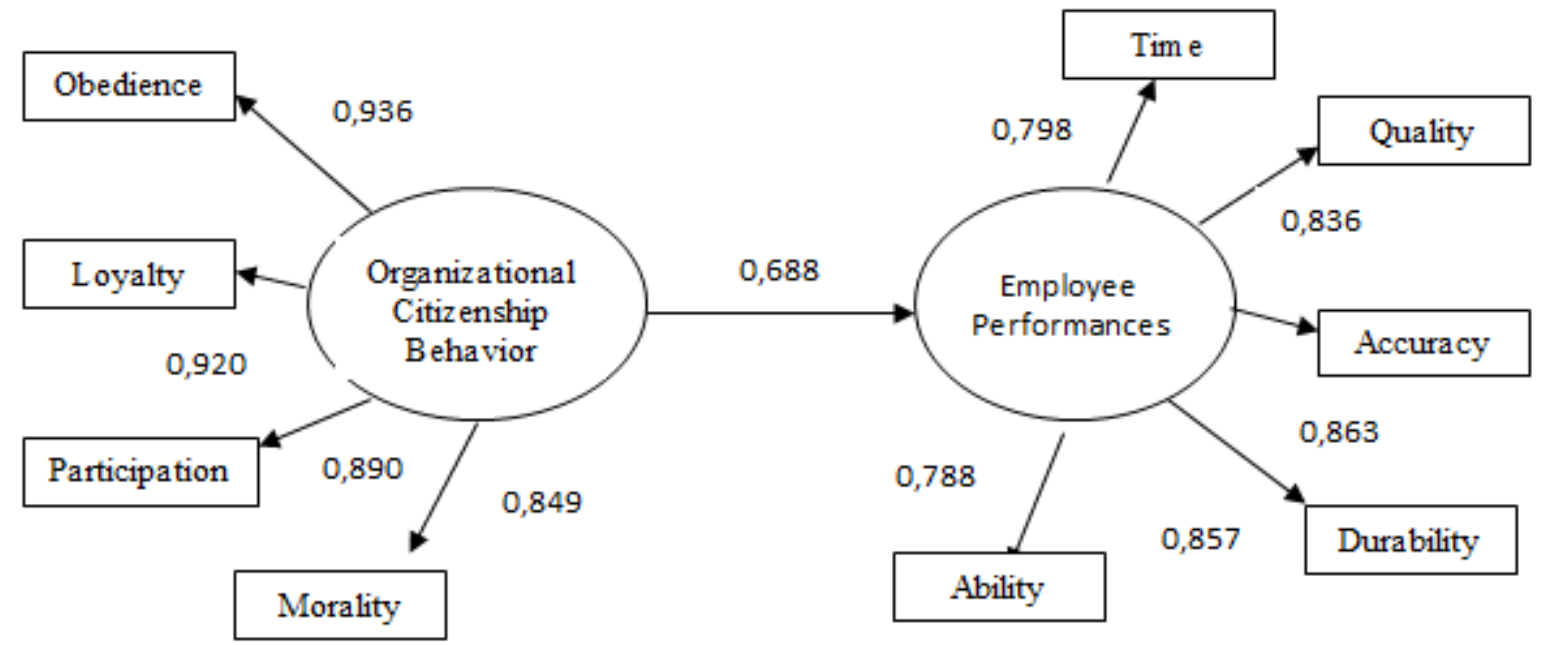

Fig. 2. PLS Result 
Based on loading factor, it can be concluded that obedience is the strongest dimension that supported organizational citizenship behavior. It means that four and five star hotel management need to put more concern in improving the obedience indicators in purpose to increase employee organizational citizenship behavior. Meanwhile working accuracy is the strongest dimension that supported employee performances. It means that four and five star hotel management need to emphasize more attention toward working accuracy indicators in order to boast employee working performances.

The hypothesis testing showed that t-statistic value is greater than 1.96 which mean research hypothesis is supported. It means that organizational citizenship behavior of employee who have been working in four and five star hotel has significant effect on their behavior. Based on this finding then four and five star hotel management need to create regular program to improve employee organizational citizenship behavior because if this behavior is increasing then it will lead to the increasing of employee performances. In addition, hotel management need to monitor each dimension along with its indicators both for employee organizational citizenship behavior and employee performances.

\section{References}

[1] A. J. Dubinsky, J. Y. Francis, and A.J. Marvin, 1995, "An examination of linkages between personal characteristic and dimension of transformational leadership", Human Science Press, Inc, page 315-334.

[2] E. Nurmianto, 2003, Analisa faktor kompetensi terhadap peningkatan prestasi kerja dan perancangan sistem penilaian kinerja karyawan berbasis sistem informasi, Jurnal Studi Bisnis Vol 1 No 2.

[3] Muafi, 2000, Pengaruh perilaku karyawan terhadap partisipasi kerja karyawan : Suatu studi empiris, Jurnal Siasat Bisnis. No 5 Vol 2

[4] K. C. Sloat, 1999, Organizational citizenship: does your firm inspire employees to be good citizens?" Professional Safety, Vol. 44, pp. 20-23.

[5] D. W. Organ, P. M. Podsakoff, and S. P. MacKenzie (2006). Organizational citizenship behavior: Its nature, antecedents, and consequences. London: Sage Publications.

[6] L. Van Dyne, J. W. Graham, R. M. Dienesch. 1994. Organizational citizenship behavior: Construct redefinition, measurement, and validation. Acad.Management Journal. 37 765-802.

https://doi.org/10.2307/256600

[7] S. E. Lovell, 1999, Does gender affect the link between organizational citizenship behavior and performance, http: //www.findarticles.com/cf_0/m2294

[8] Organ, D.W. and K, Ryan. 1994, A meta-analytic review of attitudinal and dispositional predictor of organizational citizenship behavior, Personnel Psychology Vol 74 No 1.

[9] R. Chenhall, and D. Morris, 1986, The impact of structure environment, and interdependency on perceived usefullness of management accounting system, The Accounting Review

[10]H.C. Koh, and E.H.Y. Boo, 2004. Organizational ethics and employee satisfaction and commitment, Management Decision, vol. 42 (5) p. 677-693

https://doi.org/10.1108/00251740410538514 